\title{
Effect of the larval density of Chrysodeixis includens (LEPIDOPTERA, NOCTUIDAE) on cotton yield
}

\author{
Sandra Maria Moraes RODRIGUES ${ }^{1 *}$, Rafael Major PITTA², Nubia Carmo SANTOS ${ }^{3}$ \\ ${ }^{1}$ Embrapa Algodão, Campina Grande, $\mathrm{PB}$, Brasil \\ ${ }^{2}$ Embrapa Agrossilvipastoril, Sinop, MT, Brasil. \\ ${ }^{3}$ Instituto de Ciências Agrárias e Ambientais, Universidade Federal de Mato Grosso, Sinop, MT, Brasil. \\ E-mail: sandra.rodrigues@embrapa.br
}

Recebido em julho/2018; Aceito em abril/2019.

\begin{abstract}
The cultivation of soybean near to cotton areas has favored the migration of lepidopteran pests between those crops, including the soybean looper, Chrysodeixis includens, which usually attacks soybean leaves but can also attack cotton plants. The objective of this study is to identify the density of $C$. includens larvae capable of decreasing cotton productivity. Six treatments $\left(0,2,4,6,8\right.$ and 16 larvae.meter $\left.{ }^{-1}\right)$ with five replications were arranged in a completely randomized block design. Plants of cultivar FM 944GL at stage F2 were protected by PVC cages (length, $1.0 \mathrm{~m}$; width, $1.0 \mathrm{~m}$, height, $1.6 \mathrm{~m}$ ) covered with organza fabric and infested with thirdinstar larvae. Crop yield and defoliation data were subjected to analysis of variance using the F-test and regression analysis. The results indicated that the presence of two third-instar larvae. $\mathrm{m}^{-1}$ did not affect cotton yield in the F2 phase whereas four or more third-instar larvae. $\mathrm{m}^{-1}$ decreased cotton yield. The rate of defoliation was $4 \%, 10 \%$, $6 \%, 13 \%$, and $24 \%$ in the treatments with two, four, six, eight, and sixteen larvae, respectively.
\end{abstract}

Keywords: Gossypium hirsutum; soybean looper; herbivory; management.

\section{Efeito de densidades de Chrysodeixis includens (LEPIDOPTERA, NOCTUIDAE) na produtividade do algodoeiro}

\begin{abstract}
RESUMO: A existência de plantios de soja próximos aos de algodão tem favorecido a migração de espécies de lepidópteros-praga entre essas culturas, como a falsa-medideira, Chrysodeixis includens, praga desfolhadora da soja, mas que está atacando o algodoeiro. O objetivo deste trabalho foi identificar qual a densidade de lagartas de $C$. includens que causa redução na produtividade do algodoeiro. O delineamento foi em blocos ao acaso com seis tratamentos $\left(0,2,4,6,8\right.$ e 16 lagartas.metro $\left.^{-1}\right)$ e cinco repetições. As plantas da cultivar FM 944GL, no estádio F2, foram infestadas com lagartas em terceiro instar, protegidas por gaiola de PVC (1,0 m x 1,0 m x 1,6 $\mathrm{m}(\mathrm{C} \times \mathrm{L} \times \mathrm{H}))$ revestida com organza. Os dados de produção e desfolha foram submetidos à análise de variância pelo teste $\mathrm{F}$ e análise de regressão. De acordo com os resultados constatou-se que a presença de duas lagartas.m ${ }^{1}$, de terceiro instar, de $C$. includens não afetou a produtividade do algodoeiro na fase F2; e a partir de quatro lagartas. $\mathrm{m}^{-1}$ de terceiro instar houve redução na produtividade do algodoeiro. Nos tratamentos com duas, quatro, seis, oito e dezesseis lagartas a desfolha foi de $4 \%, 10 \%, 6 \%, 13 \%$ e $24 \%$, respectivamente.
\end{abstract}

Palavras-chave: Gossypium hirsutum; falsa-medideira; herbivoria; manejo.

\section{INTRODUCTION}

The area cultivated with cotton in the state of Mato Grosso, Brazil, in the crop years 2016-2017 was 627.8 thousand hectares, corresponding to $66.9 \%$ of the total cultivated area in Brazil. The projected production of seed cotton is 2,528.2 thousand tons, with a yield of $4,027 \mathrm{~kg} \mathrm{ha}^{-1}$ (Companhia Nacional de Abastecimento - CONAB, 2017). The cost of production of cotton in Mato Grosso is high ( $\mathrm{R} \$ 8,148.59$ ha $\left.{ }^{1}\right)$ primarily because of the cost of insecticides used for managing arthropod pests. Pesticides are sprayed extensively in crops, and the number of sprays per production cycles may exceed 20. Pest control expenditures for the crop years 20162017 reached $\mathrm{R} \$ 1,727.72 \mathrm{ha}^{-1}$, corresponding to $21.2 \%$ of the total production cost (Instituto Matogrossense de Economia Agrícola - IMEA, 2017).

The existing agroecosystem in the Cerrado is composed predominantly of soybean, cotton, and corn. The large extensions of the crops and the proximity of plants to one another favor the migration of lepidopteran pests. At the end of the soybean cycle, lepidopterans migrate in search of new hosts (BUSOLI et al., 2011), including the soybean looper Chrysodeixis includens (Walker) (Lepidoptera, Noctuidae), which defoliates soybean but also infests cotton plants (PALMA et al., 2015; SPECHT et al., 2015; SANTOS et al., 2017). Although $C$. includes can grow well in cotton plants, this insect species prefers feeding on soybean plants (JOST; PITRE, 2002; ANDRADE et al., 2016). The average leaf consumption of $C$. includens may be affected not only by host plants species (ANDRADE et al., 2016) but also by their cultivars (BUENO et al. 2011). In other words, leaf consumption of $C$. includens is affected by intra and interspecific variability. The larva-adult period of $C$. includens is affected by the type of food (BARRIONUEVO et al., 2012, ANDRADE et al., 2016) and also by the cultivar of this host (FUNICHELLO et al., 2013). In the crop years 2013-2-14, the population density of $C$. includens was higher than that of all 
the lepidopteran species collected in light and Delta traps installed in the margins of cotton crops surrounded by maize and/or soybean in different regions of Mato Grosso, causing economic losses to producers (Instituto Matogrossense do Algodão - IMAmt, 2014).

Chrysodeixis includes initially attacks the lower third of cotton plants, where larvae make circular holes in the central areas of the leaves. However, defoliation can reach the middle and upper thirds of the plant, significantly reducing productivity (SILVIE et al., 2013). Infestation begins when the lateral stems of the plants cover the planting rows, decreasing the efficiency of chemical control because insecticides cannot reach the middle stems of plants. Once there is not a threshold for $C$. includes until now, the threshold for this pest is the same of cotton leafworm Alabama argillacea (Hübner) (SANTOS, 2015; SILVIE et al., 2013).

Considering the limited number of studies in Brazil on $C$. includes, the objective of this study is to determine the density of $C$. includens larvae tolerated by cotton plants without decreasing crop yield.

\section{MATERIAL AND METHODS}

The study was conducted in Sinop (coordinates 11 ${ }^{\circ} 50^{\prime} 34^{\prime}$ ' S and 55 $36^{\prime} 42^{\prime \prime}$ W), Mato Grosso, Brazil. The cultivar used in this study was FM 944GL, considered as medium-cycle (160 to 180 days) and susceptible to insect larvae but tolerant to herbicides. The replicates consisted of five 5-m rows with an inter-row spacing of $0.76 \mathrm{~m}$ and were sown on February 12, 2016. Cover crop treatment was performed, including insecticide spraying, to avoid interference of other pests in the results.

The plants in the F2 stage located in 1-m plots were infested with third-instar larvae. This plant stage corresponds to the second flower, according to the Marur; Ruano (2001) scale. Quirino; Soares (2001) and Michelotto et al. (2013) observed that this phenological phase was the most sensitive to the attack by insect defoliators. The infested plants were protected by a cage made of PVC (length, $1.0 \mathrm{~m}$; width, $1.0 \mathrm{~m}$; height, $1.6 \mathrm{~m}$ ), covered with organza fabric, and closed with Velcro, and each cage contained an average of eleven plants. For the controlled infestations, a population of $C$. includens was reared in the laboratory with an artificial diet according to Greene et al. (1976).

The larvae were allowed to feed on the plant leaves for 7 days and, at the end of this period, the cages were opened, the pupae were removed, and the cages were sprayed with insecticide to kill the larvae that had not reached the pupal stage. The percentage of defoliation was determined at one time point before infestation and one time point after infestation, according to Bleicher et al. (1981).

Six treatments $\left(0,2,4,6,8\right.$ and 16 larvae. $\left.\mathrm{m}^{-1}\right)$ with five replications were arranged in a completely randomized block design. The productivity was estimated where the larvae were released, that is, in a meter of each replication. Crop yield and defoliation data were subjected to analysis of variance using the F-test test. Regression analysis was performed, and the choice of the regression model was based on the $\mathrm{R}^{2}$ value and the significance of the parameter for each variable. The defoliation data presented a non-normal distribution and consequently were transformed as $\log \mathrm{x}+1$ before the analysis.

\section{RESULTS}

The yield of seed cotton was affected by the number of $C$. includens larvae released at the time of the second flower (F2 stage). The data were adjusted to a second-order equation with a negative correlation and a determination coefficient $\left(\mathrm{R}^{2}\right)$ of 0.7670 (Figure 1). The yields $\left(\mathrm{kg} \mathrm{ha}^{-1}\right)$ of treatment with zero, two, four, six, eight, and sixteen larvae $\mathrm{m}^{-1}$ were $1,862.67$; $1,867.25 ; 1,473.08 ; 1,579.56 ; 1,548.03 ;$ and $1,270.53$, respectively. There was no significant difference in crop yield between control and treatment plants using two larvae per plant. Yield loss was minimal $(20.9 \%)$ with four larvae $\mathrm{m}^{-1}$ and maximal $(28.7 \%)$ with 16 larvae $\mathrm{m}^{-1}$

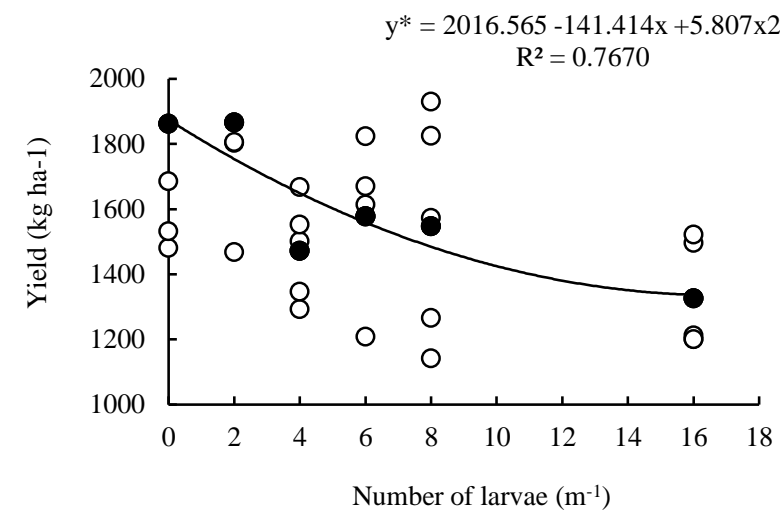

Figure 1. Mean cotton yield $\left(\mathrm{kg} \mathrm{ha}^{-1}\right)$ using different densities of third-instar larvae of $C$. includens. Sinop, Mato Grosso, Brazil, 2016. *significant at a level of significance of $5 \%$ using analysis of variance.

Figura 1. Média da produtividade $\left(\mathrm{kg} \mathrm{ha}^{-1}\right)$ do algodoeiro usando diferentes densidades de lagartas de terceiro instar de C. includens. Sinop, Mato Grosso, Brasil, 2016. *significativo a $5 \%$ de probabilidade pela análise de variância.

The analysis of defoliation indicated that the increase in the number of larvae caused significant damage to the crop, and the data adjusted to a first-degree equation presented a positive correlation and a coefficient of determination $\left(\mathrm{R}^{2}\right)$ of 0.90 (Figure 2). The presence of four larvae per cotton plant caused defoliation of $10 \%$ and decreased yield by $21.1 \%$. The rate of defoliation was $6 \%, 13 \%$ and $24 \%$ using six, eight, and sixteen larvae per plant, respectively.

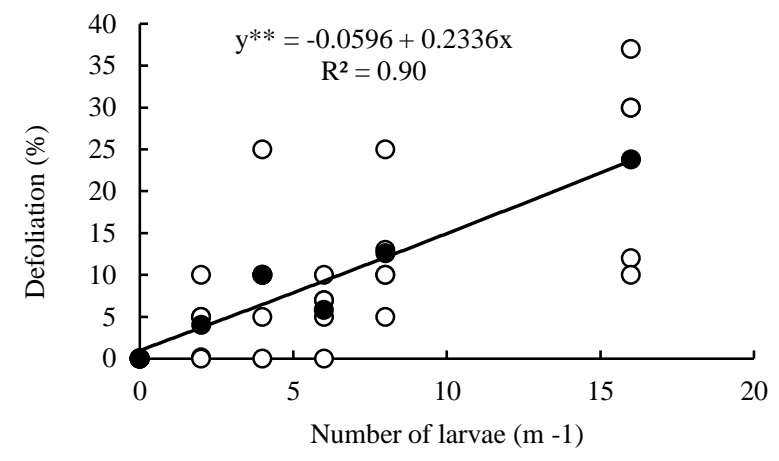

Figure 2. Defoliation (\%) after infesting cotton with thirdinstar larvae of $C$. includens. Sinop, Mato Grosso, Brazil, 2016. **significant at a level of significance of $1 \%$ using analysis of variance.

Figura 2. Desfolha (\%) em algodão após a infestação com lagartas de terceiro instar de C. includens. Sinop, Mato Grosso, 
Brasil, 2016. **significativo a $1 \%$ de probabilidade pela análise de variância.

\section{DISCUSSION}

The yield of seed cotton of the control treatment (no larvae) was $1862.67 \mathrm{~kg} \mathrm{ha}^{-1}$, and this value was lower than expected $\left(4,500 \mathrm{~kg} \mathrm{ha}^{-1}\right)$ for this cultivar. The small amount of rainfall during the reproductive phase of the crop may have significantly contributed to this result. The water demand of cotton crops from the first flowering until the development of the first bud is very high (10 $\left.\mathrm{mm} \mathrm{day}^{-1}\right)$ (BRITO, 2014); however, at this stage, the evaluated crops received only approximately $3.5 \mathrm{~mm}$ day $^{-1}$.

Considering that the larvae were released at the beginning of the reproductive phase of the plant (50 days after emergence-DAE), i.e., when the rate of photosynthesis was high in leaves and the carbohydrate reserves were allocated to the production of flowers and fruits, it was expected that injuries leading to a decrease in the leaf area affected the amount of photoassimilates produced and made available to the root system. Quirino; Soares (2001) found that the defoliation caused by A. argillacea on mainstem leaves during flower emergence affected plant growth and development. Soares et al. (1999) demonstrated that mainstem leaves accounted for more than $80 \%$ of cotton yield. Siebert et al. (2006) reported that removing the leaves located in the upper two-thirds of the mainstem to simulate a soybean looper attack decreased yield by $18 \%$. At this stage, the plant presented five mainstem nodes from the terminal to the uppermost firstposition white flower. Helman et al. (2011) protected cotton plants from the emission of the first flower to the opening of the boll of cotton leafworm A. argillacea and obtained a productivity increase of $22.6 \%$.

Larval density and the defoliation caused by larvae of $C$. includens did not affect the characteristics of the cotton fiber, and this result was also observed by Siebert et al. (2006) when simulating an herbivory attack on cotton.

Defoliation affects plant growth and photosynthetic capacity, rearranges carbon and nitrogen reserves, and accelerates root metabolism, leading to a higher source-sink ratio (IQBAL et al., 2012). Maximum photosynthesis in the leaf occurs at the beginning of fruit development but may limit the flow of carbohydrates to the fruit, especially in the presence of more than one fruit per stem (SILVA et al., 2011, ROSOLEM; ECHER, 2015). The plants can recover from defoliation, and yield is not affected when defoliation occurs in the vegetative phase (BATISTELA et al., 2012). However, recovery depends on the rate of defoliation. In this respect, Michelotto et al. (2013) observed that cotton yield was decreased at $30 \mathrm{DAE}$ (62\% defoliation), indicating that a high rate of defoliation, even in the vegetative phase, decreased productivity. This result was corroborated by Wilson et al. (2009), who found that the response of crops to herbivory depended on the time of the attack, plant development phase, duration of the attack, and the intensity and spatial distribution of injuries, among other factors.

Funichello et al. (2013) concluded that cotton cultivars affect the biological aspects of $C$. includens. It is possible that there is also genetic variability regarding defoliation tolerance among commercial cotton cultivars, as evidenced by Silva et al. (2012), whereby a rate of defoliation of up to $25 \%$ in F5 did not decrease productivity, but productivity was decreased starting at a percentage of defoliation of $50 \%$. In contrast,
Degrande (2004) reported cotton plants did not tolerate a percentage of defoliation higher than $10 \%$ in the reproductive phase. Therefore, more studies are needed to evaluate the tolerance to defoliation of currently cultivated cotton cultivars in Brazil.

\section{CONCLUSION}

The cotton cultivar of medium-cycle, FM 944GL, in phase $\mathrm{F} 2$ can tolerate up to two third-instar larvae $\mathrm{m}^{-1}$ of $C$. includens without a decrease in yield.

\section{ACKNOWLEDGMENTS}

André Filipiaki for the support in installing and executing the experiments; to the Research Support Foundation of Mato Grosso (Fundação de Amparo à Pesquisa do Mato Grosso) (Case No. 158108/2014) for funding the research.

\section{REFERENCES}

ANDRADE, K.; BUENO, A. F.; SILVA, D. M.; STECCA, C. S.; PASINI, A.; OLIVEIRA, M. C. N. Bioecological characteristics of Chrysodeixis includens (Lepidoptera: Noctuidae) fed on different hosts. Austral Entomology, Camberra, v. 55, n. 4, p. 449-454, 2016. DOI: https://dx.doi.org/10.1111/aen.12208

BARRIONUEVO, M. J.; MURÚA, M. G.; GOANE, L.; MEAGHER, R.; NAVARRO, F. Life table studies of Rachiplusia nu (Guenée) and Chrysodeixis (=Pseudoplusia) includens (Walker) (Lepidoptera: Noctuidae) on artificial diet. Florida Entomologist, Gainesville, v. 95, n. 4, p. 944-951. 2012. DOI: https://dx.doi.org/10.1653/024.095.0419

BATISTELA, M. A.; BUENO, A. F.; NISHIKAWA, M. A. N.; BUENO, R. C. O. F.; HIDALGO, G.; SILVA, L.; CORBO, E.; SILVA, R. B. Re-evaluation of leaf-lamina consumer thresholds for IPM decisions in short-season soybeans using artificial defoliation. Crop Protection, Guildford, v. 32, sn, p. 7-11, 2012. DOI: https://dx.doi.org/10.1016/j.cropro.2011.10.014

BLEICHER, E.; SILVA, A. L. da; SANTOS, W. J. dos; GRAVENA, S.; NAKANO, O.; FERREIRA, L. Manual de manejo integrado das pragas do algodoeiro. Campina Grande: Embrapa Algodão, 1981. 15 p. (Documentos, 02).

BRITO, G. G. Parâmetros físiológicos para seleção de cultivares tolerantes ao déficit hídrico. In: ECHER, F. R. O algodoeiro e os estresses abióticos: temperatura, luz, água e nutrientes. 1. ed., Cuiabá: IMAmt, 2014, 1, p. 79101.

BUENO, R. C. O.; BUENO, A. F.; MOSCARDI, F.; PARRA, J. R. P.; HOFFMANN-CAMPO, C. B. Lepidopteran larvae consumption of soybean foliage: basis for developing multiple-species economic thresholds for pest management decisions. Pest Management Science, Sussex, v. 67, n. 2, p. 170-174. 2011. DOI: https://dx.doi.org/10.1002/ps.2047

BUSOLI, A. C.; GRIGOLLI, J. F. J.; FRAGA, D. F.; SOUZA, L. A.; FUNICHELLO, M.; NAIS, J.; SILVA, E. A. Atualidades no MIP algodão no cerrado brasileiro. In: BUSOLI, A. C.; FRAGA, D. F.; SANTOS, L. C.; ALENCAR, J. R. C. C.; GRIGOLLI, J. F. J.; JANINI, J. C.; SOUZA, L. A.; VIANA, M. A.; FUNICHELLO, M. (Org.). Tópicos em Entomologia Agrícola - IV. 1. ed. 
Jaboticabal, SP.: Gráfica e Editora Multipress Ltda., 2011, v. 1 , p. $117-138$

CONAB_COMPANHIA NACIONAL DE ABASTECIMENTO. Acompanhamento da safra brasileira de grãos: décimo segundo levantamento. Companhia Nacional de Abastecimento, Brasília: v.4. 158p, setembro/2017. Available in: 〈www.conab.gov.br〉. Access in: October, 26, 2017.

DEGRANDE, P. E. Níveis de controle das pragas do algodoeiro. Atualidades Agrícolas, São Paulo, v. 1, n. 1, p. 22-23, 2004.

FUNICHELLO, M.; GRIGOLLI, J. F. J.; SOUZA, B. H. S.; BOIÇA JUNIOR, A. L.; BUSOLI, A. C. Effect of transgenic and non-transgenic cotton cultivars on the development and survival of Pseudoplusia includens (Walker) (Lepidoptera: Noctuidae). African Journal of Agricultural, Pretoria, v. 8, n. 44, p. 5424-5428, 2013.

GREENE, G. L.; LEPPLA, N. C.; DICKERSON, W.A. Velvetbean caterpillar: a rearing procedure and artificial medium. Journal of Economic Entomology, Lanham, v. 69, n. 4, p. 487-488. 1976.

HELMAN, S. A.; BELTRAN, R. E.; GARAY, F.; RAÑA, E. Efecto de las poblaciones de Alabama argillacea (Hübner) (Lepidoptera: Noctuidae) em los cultivos de algodón a dos distanciamentos. Neotropical Entomology, Londrina, v. 40, n. 2, p. 251-257, 2011.

IMAmt_INSTITUTO MATOGROSSENSE DO ALGODÃO. Informativo $\mathrm{n}^{\circ} 003$ SAP-e (Safra 2013/2014 - Mato Grosso). 6p. 2014.

IMEA_INSTITUTO MATOGROSSENSE DE ECONOMIA AGRÍCOLA. Custo de produção do algodão- safra 2017/18. Available

in: <http://www.imea.com.br/upload/publicacoes/arquivos/0 6122017125834.pdf> Access in: November, 08, 2017.

IQBAL, N.; MASOOD, A.; KHAN, N. A. Analyzing the significance of defoliation in growth, photosynthetic compensation and source-sink relations. Photosynthetica, Prague, v. 50, n. 2, p. 161-170, 2012. DOI: https://dx.doi.org/10.1007/s11099-012-0029-3

JOST, D. J.; PITRE, H. N. Soybean looper (Lepidoptera: Noctuidae) oviposition on cotton and soybean of different growth stages: influence of olfactory stimuli. Journal of Economic Entomology, Lanham, v. 95, n. 2, p. 286-293. 2002. DOI: https://dx.doi.org/10.1603/0022-049395.2.286

MARUR, C. J.; RUANO, O. A reference system for determination of cotton plant development. Revista Oleaginosas e Fibrosas, Campina Grande, v. 5, n. 2, p. 313-317, 2001.

MICHELOTTO, M. D.; GALLI, J. A.; CROSARIOL NETTO, J.; PIROTTA, M. Z.; BUSOLI, A. C. Efeito do nível e da época de desfolha artificial sobre os componentes de produtividade de cultivares de Algodoeiro. Biosciense Journal, Uberlândia, v. 29, n. 6, p. 1806-1814, 2013.

PALMA, J.; MAEBE, K.; GUEDES, J. V. C.; SMAGGHE, G. Molecular variability and genetic structure of Chrysodeixis includens (Lepidoptera: Noctuidae), an important soybean defoliator in Brazil. PLoS ONE, San Franscico, v. 10, n. 3, p. 1-13, 2015. DOI: https://dx.doi.org/10.1371/journal.pone.0121260
QUIRINO, E. S.; SOARES, J. J. Efeito do ataque de Alabama argillacea no crescimento vegetativo e sua relação com a fenologia do algodoeiro. Pesquisa Agropecuária Brasileira, Brasília, v. 36, n. 8, p. 1005-1010, 2001.

ROSOLEM, C. A.; ECHER, F. R. Ecofisiologia do algodoeiro: implicações na época de semeadura $\mathrm{e}$ qualidade. In: FREIRE, E. C Algodão no Cerrado do Brasil. 3. ed. Brasília: ABRAPA. 2015, p. 533-558.

SANTOS, W. J. Manejo das pragas do algodão com destaque para o cerrado brasileiro. In: FREIRE, E. C. Algodão no Cerrado do Brasil. 3. ed. Brasília: ABRAPA. 2015, p. 267-347.

SANTOS, S. R.. SPECHT, A.; CARNEIRO, E.; DE PAULAMORAES, S. V.; CASAGRANDE, M. M. Interseasonal variation of Chrysodeixis includens (Walker, [1858]) (Lepidoptera: Noctuidae) populations in the Brazilian Savanna. Revista Brasileira de Entomologia, Curitiba, v. 61, n. 4, p. 294-299, 2017. DOI: https://dx.doi.org/10.1016/j.rbe.2017.06.006

SIEBERT, J. D.; LEONARD, B. R.; STEWART, A. M. Cotton (Gossypium hirsutum L.) yield and fiber quality response to premature insect-simulated and harvest-aid defoliation. Journal of Cotton Science. Memphis, v. 10, n. 1, p. 9-16, 2006.

SILVA, I. P. F.; JUNIOR, J. F. S.; ARALDI, R.; TANAKA, A. A.; GIROTTO, M.; BOSQUÊ, G. G.; LIMA, F. C. C. Estudo das fases fenológicas do algodão (Gossypium hirsutum L.). Revista Científica Eletrônica de Agronomia, Garça, Ano X, n. 20, dezembro de 2011. Available <http://faef.revista.inf.br/imagens_arquivos/arquivos_dest aque/1KGx8imgN0FVRW1_2013-5-17-17-34-45.pdf.> Access in: November, 17, 2017.

SILVA, M. S.; DEGRANDE, P. E.; SUEKANE, R.; FERNANDES, M. G.; ZEVIANE, W. M. Impacto de diferentes níveis de desfolha artificial nos estádios fenológicos do algodoeiro. Revista de Ciências Agrárias, Lisboa, v. 35, n. 1, p. 163-172, 2012.

SILVIE, P. J.; THOMAZONI, D.; SORIA, M. F.; SARAN, P. E.; BÉLOT, J. L. Pragas e Seus Danos em Algodoeiro. Cascavel: IGOL. 2013. 184 p. (Boletim Técnico IMAmt, 1)

SOARES, J. J. LARA, F. M.; SILVA, C. A. D.; ALMEIDA, R. P.;WANDERLEY, D. S. Influência da posição do fruto na planta sobre a produção do algodoeiro. Pesquisa Agropecuária Brasileira, Brasília, v. 34, n. 5, p. 755-759, 1999.

SPECHT, A., DE PAULA-MORAES, S. V.; SOSA-GÓMEZ, D. R. Host Plants of Chrysodeixis includens (Walker) (Lepidoptera, Noctuidae, Plusiinae). Revista Brasileira de Entomologia, Curitiba, v. 59, n. 4, p. 343-345, 2015. DOI: https://dx.doi.org/10.1016/j.rbe.2015.09.002

WILSON, L. J.; LEI, T. T.; SADRAS, V. O.; WILSON, L. T.; HEIMOANA, S. C. Undamaged cotton plants yield more if their neighbour is damaged: implications for pest management. Bulletin of Entomological Research, Farnham Royal, v. 99, n. 5, p. 467-478, 2009. DOI: https://dx.doi.org/10.1017/S0007485308006500 